\title{
Pembelajaran Biologi Menggunakan Pendekatan Metakognitif melalui Model Reciprocal Taching dan Problem Based Learning Ditinjau dari Kemandirian Belajar dan Kemampuan Berpikir Kritis Mahasiswa
}

\author{
Afandi \\ Pendidikan Biologi, FKIP Universitas Tanjungpura
}

\begin{abstract}
Abstrak
Tujuan penelitian ini adalah untuk mengetahui pengaruh pendekatan metakognitif model Reciprocal Teaching (RT) dan Problem Based Learning (PBL), kemandirian belajar dan kemampuan berpikir kritis serta interaksinya terhadap prestasi belajar mahasiswa. Penelitian ini merupakan penelitian eksperimental faktorial $2 \times 2 \times 2$ dengan subjek penelitian seluruh mahasiswa P.MIPA yang mengambil mata kuliah Biologi Umum tahun ajaran 2011/2012. Hasil penelitian menunjukkan: (1) pembelajaran dengan pendekatan metakognitif model PBL secara signifikan lebih baik dibandingkan model RT; (2) kemandirian belajar tinggi secara signifikan lebih baik dibandingkan kemandirian belajar rendah; (3) kemampuan berpikir kritis tinggi secara signifikan lebih baik dibandingkan kemampuan berpikir kritis rendah; (4) terdapat interaksi antara model pembelajaran dengan kemandirian belajar; (5) terdapat interaksi antara model pembelajaran dengan kemampuan berpikir kritis; (6) tidak terdapat interaksi antara kemandirian belajar dan kemampuan berpikir kritis; (7) tidak terdapat interaksi antara model pembelajaran dengan kemandirian belajar dan kemampuan berpikir kritis.
\end{abstract}

Kata kunci : metakognitif, reciprocal teaching, problem based learning, kemandirian belajar, kemampuan berpikir kritis

\section{Pendahuluan}

Sains memiliki peranan penting dalam perkembangan ilmu pengetahuan dan teknologi saat ini. Pembelajaran sains di berbagai jenjang pendidikan termasuk perguruan tinggi seharusnya berpijak pada hakikat sains yakni produk, proses, dan sikap ilmiah. Pelaksanaan pembelajaran sains yang berpijak pada hakikat sains seharusnya dapat menjadi pondasi bagi pengembangan Ilmu Pengetahuan dan Teknologi (IPTEK) ke depan. Peranan tersebut belum sepenuhnya didukung oleh proses pembelajaran sains yang semestinya. Sains masih sering dianggap sebagai kendala bagi banyak peserta didik maupun tenaga pengajar. Pembelajaran sains di berbagai jenjang pendidikan hanya dipandang sebagai kewajiban dalam menjalankan kurikulum, kehilangan daya tariknya, dan lepas relevansinya dengan dunia nyata yang seharusnya menjadi objek ilmu pengetahuan tersebut.

Kondisi tersebut juga diperburuk dengan munculnya berbagai persepsi bahwa 
pembelajaran sains (termasuk biologi) merupakan pelajaran yang sulit dan kompleks, membosankan, bersifat hafalan, dan hanya siswa tertentu saja yang dapat menguasainya.

Melihat kenyataan diatas, diperlukan upaya revitalisasi proses pembelajaran termasuk pada proses pendidikan calon guru sains. Sharma (1983) mengemukakan bahwa "kualitas pendidikan sains sangat bergantung pada kualitas guru sains, bukan pada fasilitas dan material semata". Dengan adanya kenyataan tersebut, tampaknya upaya peningkatan kualitas guru sains (termasuk guru biologi) melalui pendidikan calon guru perlu ditangani lebih serius lagi.

Pembelajaran yang berlangsung bagi calon guru sains dalam pelaksanaannya tidak cukup hanya membekali mereka dengan berbagai pengetahuan, tetapi lebih dari itu diperlukan adanya upaya nyata yang dilakukan secara intensif untuk menumbuh kembangkan kesadaran belajar, kemampuan dalam memecahkan masalah, kecakapan berpikir tingkat tinggi, dan kemampuan menerapkannya dalam situasi masyarakat saat ini.

Kenyataan di lapangan menunjukan menunjukan bahwa kegiatan perkuliahan bagi calon guru yang berlangsung belum banyak mencerminkan pembelajaran sains yang semestinya. Pelaksanaan perkuliahan yang terjadi selama ini masih di dominasi dengan metode ceramah, berorientasi pada buku teks, diktat dan power point dosen, belum mengarah kepada upaya pemecahan masalah dan kemampuan berpikir tingkat tinggi, serta masih lemahnya kesadaran belajar yang dimiliki oleh banyak mahasiswa.

Hal ini berakibat pada rendahnya prestasi belajar mahasiswa yang tercermin dari data nilai akhir mahasiswa yang dihimpun pada mata kuliah Biologi Umum tahun akademik 2010/2011 yakni sekitar 56 $\%$ dari 43 orang mahasiswa memperoleh nilai $\mathrm{B}$ atau dibawah target pencapaian prestasi yang diharapkan.

Berpijak dari permasalahanpermasalahan di atas, maka implikasi terpenting dalam proses pembelajaran sains (terutama biologi) adalah mewujudkan suatu suatu bentuk pembelajaran alternatif yang dirancang untuk meningkatkan keterlibatan mahasiswa secara aktif dalam menanamkan kesadaran kognisi mereka sendiri.

Upaya tersebut dapat diwujudkan dengan menerapkan pendekatan pembelajaran yang sesuai yakni dengan pendekatan metakognitif. Sehingga diharapkan proses perkuliahan akan menitikberatkan kepada aktivitas belajar, membantu dan membimbing mahasiswa jika ada kesulitan serta membantu mahasiswa untuk mengembangkan kesadaran metakognisinya.

Model pembelajaran yang digunakan dalam penelitian ini adalah model Reciprocal Teaching (RT) dan Problem Based Learning (PBL). Dipilihnya kedua model pembelajaran tersebut karena landasan utamanya adalah adanya kebebasan bagi peserta didik untuk dapat menggembangkan cara berpikir mereka sendiri dengan menggunakan strategi belajar tertentu dengan tepat yang memudahkan mereka dalam belajar dan 
memecahkan masalah belajar sesuai dengan prinsip yang dimiliki oleh pendekatan metakognitif.

Keberhasilan proses pembelajaran tidak semata-mata dipengaruhi oleh pelaksanaan pembelajaran di kelas. Berbagai faktor baik internal maupun eksternal yang telah diteliti meyakinkan bahwa bahwa kedua faktor tersebut memberi kontribusi yang besar terhadap perkembangan kognitif peserta didik, namun berbagai faktor tersebut belum mendapat perhatian dari banyak tenaga pengajar di kelas.

Salah satu faktor penting yang dapat mempengaruhi pencapaian prestasi belajar adalah kemandirian belajar dan kemampuan berpikir kritis. Menurut Zimmerman (1990) "kemandirian belajar merupakan cara seseorang membangun pikiran, perasaan, strategi, dan perilaku yang diorientasikan ke arah pencapaian tujuan belajar". Sedangkan kemampuan berpikir kritis digambarkan sebagai "proses aktif yang melibatkan peran yang dimainkan oleh metakognisi (berpikir tentang pemikiran sendiri)" (Fisher, 2010).

Implementasi pembelajaran dengan pendekatan metakognitif menggunakan model Reciprocal Teaching (RT) dan Problem Based Learning (PBL) diharapkan memberikan kontribusi yang cukup signifikan dalam perbaikan proses belajar-mengajar, khususnya dalam menumbuhkembangkan kemandirian belajar, kemampuan berpikir kritis dan kesadaran metakognisi.

\section{Metodologi Penelitian}

Penelitian ini dilaksanakan di FKIP Universitas Tanjungpura
Pontianak. Penelitian dilaksanakan pada bulan Desember 2011 - Januari 2012. Penelitian ini menggunakan metode eksperimen. Kelompok eksperimen I diajar dengan model RT sedangkan kelompok eksperimen II diajar dengan model PBL.

Rancangan penelitian ini menggunakan desain faktorial dengan rancangan penelitian Anava tiga jalan 2 X 2 X 2. Variabel bebas meliputi model RT dan PBL, variabel terikat adalah prestasi belajar mahasiswa dan variabel moderator meliputi kemandirian belajar dan kemampuan berpikir kritis.

Pengumpulan data dilakukan dengan menggunakan tes untuk mengukur prestasi belajar dan kemampuan berpikir kritis serta angket untuk mengukur kemandirian belajar. Data kemandirian belajar dan kemampuan berpikir kritis diperoleh sebelum sampel diberikan perlakuan, sedangkan data prestasi belajar diperoleh setelah sampel diberikan perlakuan.

Data yang diperoleh selanjutnya dianalisis secara deskriptif kemudian dilanjutkan dengan uji statistik Anava dan uji Scheffe jika terdapat interaksi. Uji statistik dilakukan pada taraf signifikansi 5\%. Sebelum dilakukan analisis statistik dilakukan uji prasyarat, yaitu uji homogenitas dan uji normalitas terhadap data yang diperoleh.

\section{Hasil Penelitian dan Pembahasan}

Data penelitian ini diperoleh melalui tes kemampuan berpikir kritis, angket kemandirian belajar, dan tes prestasi belajar. Deskripsi data kemandirian belajar (KB), kemampuan berpikir kritis (KBK) disajikan pada Tabel 1. 
Tabel 1. Deskripsi Data Kemandirian Belajar dan Kemampuan Berpikir Kritis Mahasiswa

\begin{tabular}{|c|c|c|c|c|}
\hline \multirow{2}{*}{ Kelas } & \multicolumn{2}{|c|}{ KB } & \multicolumn{2}{c|}{ KBK } \\
\cline { 2 - 5 } & $\bar{X}$ & SD & $\bar{X}$ & SD \\
\hline $\begin{array}{c}\text { Eksperimen } \\
\text { I }\end{array}$ & 127,93 & 9,35 & 41,03 & 3,87 \\
\hline $\begin{array}{c}\text { Eksperimen } \\
\text { II }\end{array}$ & 123,70 & 9,84 & 40,00 & 4,22 \\
Catatan: Skor tertinggi KB:160 \\
Skor tertinggi KBK : 60
\end{tabular}

Tabel 1 menunjukkan bahwa rata-rata kemandirian belajar dan kemampuan berpikir kritis mahasiswa pada kelas eksperimen I lebih baik dibandingkan kelas eksperimen II. Sedangkan rangkuman deskripsi data prestasi belajar mahasiswa berdasarkan model pembelajaran, kemandirian belajar dan kemampuan berpikir kritis mahasiswa dapat dilihat pada Tabel 2.

Tabel 2. Deskripsi rata-rata prestasi belajar mahasiswa menurut variabel penelitian

\begin{tabular}{|l|l|c|}
\hline \multicolumn{2}{|c|}{ Variabel Penelitian } & \multicolumn{1}{|c|}{$\begin{array}{c}\text { Rerata } \\
\text { Prestasi } \\
\text { Belajar }\end{array}$} \\
\hline $\begin{array}{l}\text { Model } \\
\text { Pembelajaran }\end{array}$ & PBL & 70,68 \\
\cline { 2 - 3 } $\begin{array}{l}\text { Kemandirian } \\
\text { Belajar }\end{array}$ & RT & 67,10 \\
\cline { 2 - 3 } $\begin{array}{l}\text { Kemampuan } \\
\text { Berpikir Kritis }\end{array}$ & Rendah & 71,46 \\
\cline { 2 - 3 } & Tinggi & 66,44 \\
\hline Rendah & 66,71 \\
\hline
\end{tabular}

Catatan: Skor tertinggi Prestasi Belajar: 100

Data deskriptif yang diperoleh tersebut kemudian diolah menggunakan analisis statistik anava 3 jalan $2 \times 2 \times 2$ dan dilanjutkan dengan uji Scheffe. Rangkuman hasil uji statistik Anava dan uji Scheffe disajikan pada Tabel 3 dan Tabel 4.
Tabel 3. Rangkuman Anava Prestasi Belajar

\begin{tabular}{|c|l|c|c|}
\hline $\begin{array}{c}\text { N } \\
\text { o }\end{array}$ & \multicolumn{1}{|c|}{ Source } & $\begin{array}{c}\text { p- } \\
\text { value }\end{array}$ & $\begin{array}{c}\text { Kesimpulan } \\
\text { Uji }\end{array}$ \\
\hline 1. & $\begin{array}{l}\text { Model } \\
\text { Pembelajaran }\end{array}$ & 0,045 & Di tolak \\
\hline 2. & $\begin{array}{l}\text { Kemandirian } \\
\text { Belajar }\end{array}$ & 0,000 & Di tolak \\
\hline 3. & $\begin{array}{l}\text { Kemampuan } \\
\text { Berpikir Kritis }\end{array}$ & 0,021 & Ditolak \\
\hline 4. & $\begin{array}{l}\text { Model*Keman } \\
\text { dirian belajar }\end{array}$ & 0,025 & Ditolak \\
\hline 5. & $\begin{array}{l}\text { Model*Kema } \\
\text { mpuan } \\
\text { Berpikir kritis }\end{array}$ & 0,030 & Di tolak \\
\hline 6. & $\begin{array}{l}\text { Kemandirian } \\
\text { belajar*berpik } \\
\text { ir kritis }\end{array}$ & 0,995 & Diterima \\
\hline 7. & $\begin{array}{l}\text { Model*keman } \\
\text { dirian } \\
\text { belajar*berpik } \\
\text { ir kritis }\end{array}$ & 0,821 & Diterima \\
\hline
\end{tabular}

Tabel 4. Hasil Uji Lanjut Pasca Anava (Scheffe)

\begin{tabular}{|c|c|c|c|c|c|}
\hline \multirow{2}{*}{$\begin{array}{c}\text { Inter I- } \\
\mathrm{J}\end{array}$} & \multirow{2}{*}{$\begin{array}{l}\text { Inter } \\
\text { I-J }\end{array}$} & \multicolumn{2}{|c|}{$\begin{array}{l}\text { Model * } \\
\text { Kemandiri } \\
\text { an }\end{array}$} & \multicolumn{2}{|c|}{$\begin{array}{c}\text { Model * } \\
\text { Berpikir } \\
\text { Kritis }\end{array}$} \\
\hline & & $\begin{array}{c}\mathrm{X} \\
(\mathrm{I}- \\
\mathrm{J})\end{array}$ & Sig & $\begin{array}{c}\mathrm{X} \\
(\mathrm{I}- \\
\mathrm{J})\end{array}$ & Sig \\
\hline \multirow{3}{*}{$\begin{array}{l}\mathrm{PBL}_{-} \\
\mathrm{KBT}\end{array}$} & $\begin{array}{c}\mathrm{PBL}_{-} \mathrm{K} \\
\mathrm{BR}\end{array}$ & $\begin{array}{c}4,1 \\
4\end{array}$ & $\begin{array}{c}0,27 \\
9\end{array}$ & $\begin{array}{c}3,8 \\
5\end{array}$ & $\begin{array}{c}0,34 \\
6\end{array}$ \\
\hline & $\begin{array}{c}\text { RL_K } \\
\text { BT }\end{array}$ & $\begin{array}{c}2,3 \\
7\end{array}$ & $\begin{array}{c}0,74 \\
4\end{array}$ & $\begin{array}{c}2,8 \\
2\end{array}$ & $\begin{array}{c}0,62 \\
9\end{array}$ \\
\hline & $\begin{array}{c}\mathrm{RL}_{-} \mathrm{K} \\
\mathrm{BR}\end{array}$ & $\begin{array}{l}7,3 \\
1^{*}\end{array}$ & $\begin{array}{c}0,00 \\
4^{*}\end{array}$ & $\begin{array}{l}7,1 \\
5^{*}\end{array}$ & $\begin{array}{c}0,00 \\
7 *\end{array}$ \\
\hline \multirow{3}{*}{$\underset{\mathrm{BR}}{\mathrm{PBL} K}$} & $\begin{array}{c}\mathrm{PBL} K_{-} \\
\mathrm{BT}^{-}\end{array}$ & $\begin{array}{c}- \\
4,1 \\
4\end{array}$ & $\begin{array}{c}0,27 \\
9\end{array}$ & $\begin{array}{c}4,3 \\
3\end{array}$ & $\begin{array}{c}0,25 \\
1\end{array}$ \\
\hline & $\begin{array}{c}\mathrm{RL} \mathrm{K}_{\mathrm{BT}} \\
\mathrm{B}\end{array}$ & $\begin{array}{c}- \\
1,7 \\
7\end{array}$ & $\begin{array}{c}0,89 \\
5\end{array}$ & $\begin{array}{c}1,0 \\
3\end{array}$ & $\begin{array}{c}0,97 \\
5\end{array}$ \\
\hline & $\begin{array}{c}\mathrm{RL} K \\
\mathrm{BR}\end{array}$ & $\begin{array}{c}3,1 \\
7\end{array}$ & $\begin{array}{c}0,50 \\
9\end{array}$ & $\begin{array}{c}3,2 \\
9\end{array}$ & $\begin{array}{c}0,47 \\
8\end{array}$ \\
\hline
\end{tabular}




\section{Pembahasan}

Secara deskriptif (Tabel 2) hasil penelitian ini menunjukan bahwa rata-rata prestasi belajar mahasisswa yang diajar menggunakan model PBL $(70,68)$ lebih baik dibandingkan model RT $(67,10)$, demikian pula mahasiswa yang memiliki kemandirian belajar $(71,46)$ dan kemampuan berpikir kritis $(71,18)$ tinggi menghasilkan rata-rata prestasi belajar yang lebih baik dibandingkan mahasiswa yang memiliki kemandirian belajar $(66,44)$ dan kemampuan berpikir kritis $(66,71)$ rendah.

Melalui pengujian statistik (tabel 3) diperoleh hasil bahwa model pembelajaran, kemandirian belajar dan kemampuan berpikir kritis memberikan pengaruh yang signifikan terhadap prestasi belajar mahasiswa.

Temuan lainnya menunjukan bahwa terdapat interaksi yang signifikan antara model pembelajaran dan kemandirian belajar serta model pembelajaran dan kemampuan berpikir kritis mahasiswa. Namun tidak ditemukan interaksi antara kemandirian belajar dan kemampuan berpikir kritis ataupun interaksi antara model pembelajaran, kemandirian belajar dan kemampuan berpikir kritis mahasiswa.

Hasil pengujian lanjut pasca anava (Tabel 4) menunjukan bahwa mahasiswa yang memiliki kemandirian belajar dan kemampuan berpikir kritis tinggi diajar dengan model PBL secara signifikan berbeda dengan mahasiswa yang memiliki kemandirian belajar dan kemampuan berpikir kritis rendah diajar dengan model RT.
Temuan tersebut sejalan dengan penelitian yang dilakukan oleh Fauzi (2011) yang menyatakan bahwa adanya interaksi antara pendekatan metakognitif (group dan klasikal) dengan kemandirian belajar secara bersama-sama memberikan pengaruh yang signifikan terhadap prestasi belajar dan sikap ilmiah siswa. Perwujudan kemandirian belajar yang telah dimiliki mahasiswa tersebut pada akhirnya akan mendorong mereka untuk senantiasa berusaha mencari informasi-informasi yang relevan guna meningkatkan prestasi belajarnya.

Salah satu keunggulan yang dimiliki model PBL dibandingkan model RT adalah adanya masalah kontekstual yang sifatnya tidak terstruktur (ill-structured) yang menjadikan model ini mampu memberikan stimulus lebih bagi perkembangan kognisi mahasiswa. Proses pembelajaran yang diawali dengan penyajian masalah dan dilanjutkan dengan analisis masalah dalam kelompok-kelompok kecil sampai pada penemuan konsep, ataupun prinsip untuk memecahkan masalah merupakan wahana yang sangat baik dalam meningkatkan prestasi belajar.

Lebih lanjut, Pierce \& Jones (dalam Runi, 2005) menggemukakan beberapa hal yang menjadikan pembelajaran dengan pendekatan metakognitif model PBL penting dalam pembentukan sikap dan aktivitas belajar antara lain: (1). Keterlibatan dalam keseluruhan proses pembelajaran; (2). Investigasi yang mencakup eksplorasi dan distribusi informasi (3). Performansi yaitu menyajikan temuan dan (4). Diskusi. Oleh karena itu, 
pembelajaran dengan pendekatan metakognitif melalui model PBL patut dipertimbangkan sebagai wahana untuk meningkatkan sikap dan aktivitas belajar mahasiswa.

Mencermati hasil bahwa kemandirian belajar dan kemampuan berpikir kritis sangat mempengaruhi prestasi belajar, kenyataan dilapangan menunjukan bahwa mahasiswa yang memiliki kemandirian belajar dan kemampuan berpikir kritis tinggi lebih rendah jumlahnya dibandingkan mahasiswa yang memiliki kemandirian belajar dan kemampuan berpikir kritis rendah.

Secara teoretik, hal ini berbeda dengan pandangan Piaget (dalam Sadia, 2007). Semestinya, seseorang dengan rentangan umur diatas 17 tahun sudah memiliki kemandirian belajar dan kemampuan berpikir pada kualifikasi tinggi, jika kelima faktor penentu perkembangan intelektual siswa, yaitu: (1) kedewasaan; (2) pengalaman fisik; (3) pengalaman logikal; (4) transmisi sosial dan (5) pengaturan-diri berinteraksi dan berkontribusi secara optimal dalam pengembangan intelektual anak. Tampaknya teori Piaget tentang perkembangan intelektual anak bahwa anak yang telah berusia 11 tahun ke atas sudah mencapai high order thinking skils (HOTS) kurang sesuai dengan kondisi mahasiswa di Universitas Tanjungpura.

\section{Penutup}

Adapun kesimpulan penelitian ini antara lain sebagai berikut: (1) prestasi belajar kognitif mahasiswa yang diajar menggunakan pendekatan metakognitif melalui model PBL lebih baik dibandingkan model RL; (2) prestasi belajar kognitif mahasiswa yang memiliki kemandirian belajar tinggi lebih baik dibandingkan mahasiswa yang memiliki kemandirian belajar rendah; (3) prestasi belajar kognitif mahasiswa yang memiliki kemampuan berpikir kritis tinggi lebih baik dibandingkan mahasiswa yang memiliki kemampuan berpikir kritis rendah; (4) pembelajaran dengan pendekatan metakognitif model PBL dan RL secara bersamasama dengan kemandirian belajar mempengaruhi secara signifikan prestasi belajar mahasiswa pada aspek kognitif mahasiswa; (5) pembelajaran dengan pendekatan metakognitif model PBL dan RL secara bersamasama dengan kemampuan berpikir kritis mempengaruhi secara signifikan prestasi belajar mahasiswa pada aspek kognitif mahasiswa; (6). secara bersama-sama (interaksi) antara variabel kemandirian belajar (tinggi dan rendah) dan variabel kemampuan brpikir kritis (tinggi dan rendah) tidak memberikan hasil yang signifikan dalam mempengaruhi prestasi belajar kognitif mahasiswa; (7) secara bersama-sama (interaksi) antara variabel kemandirian belajar (tinggi dan rendah), variabel kemampuan berpikir kritis (tinggi dan rendah) dan variabel penerapan pembelajaran baik dengan menggunakan pendekatan metakognitif melalui model PBL maupun pendekatan metakognitif melalui model RL tidak memberikan hasil yang signifikan dalam mempengaruhi prestasi belajar kognitif mahasiswa.

\section{Daftar Pustaka}

Fauzi, $\begin{array}{cr}\text { A. 2011. } \\ \text { Kemampuan } \\ \text { Matematis }\end{array} \begin{array}{r}\text { Peningkatan } \\ \text { Koneksi } \\ \text { dan }\end{array}$


Kemandirian Belajar

Siswa Dengan Pendekatan

Pembelajaran Metakognitif

di Sekolah Menengah

Pertama. Desertasi. PPS UPI Bandung (Unpublished)

Fisher, A. 2009. Berfikir Kritis;

Sebuah Pengantar. Jakarta:

Erlangga

Runi. 2005. Meningkatkan

Kemampuan Pemecahan

Masalah Siswa Pada Mata

Pelajaran Sains Konsep

Pencemaran Lingkungan

di Kelas VII SMP Melalui Pembelajaran Berbasis

Masalah. Tesis. Program Pasca Sarjana UPI Bandung (Unpublished)
Sadia, I.W. 2007. Pengembangan Kemampuan Berpikir Formal Siswa SMA Melalui Penerapan Model Pembelajaran "Problem Based Learning" Dan "Cycle Learning" Dalam Pembelajaran Fisika. Pendidikan dan Pengajaran UNDHIKSA, 1 (1):1-20

Sharma, R.C. 1983. Modern Science Teaching. New Delhi: Dhanpat Rai and Sons

Zimmerman, B.J. 1990. Self Regulated Learning and Academic Achievement: An Overview. Educational Psychologist, 25(1); 3-1 
Pembelajaran Biologi Menggunakan (Afandi) 8 